\title{
Hubungan Empathy dengan Loneliness pada Anak Panti Asuhan Evangeline Booth dan Wiliam Both Medan
}

\author{
Yunike Cheria, Gloria Tarafang, Setiyo Wibowo, Calvian Tanur, Aleksander Agung Wijaya, \\ Diny Atrizka \\ Fakultas Psikologi, Universitas Prima Indonesia, Medan, Indonesia
}

Email: yunikechr@gmail.com, tarafang21@yahoo.com, bowosenggromg@gmail.com, calvian213@gmail.com, wijayaalexander96@gmail.com,diny.dinyrizk@gmail.com

\begin{abstract}
This study aims to determine the relationship between empathy with loneliness of children at the Putri Evangeline Booth Orphanage and Putra Wiliam Booth Orphanage. This research was conducted at Putri Evangeline Booth Orphanage located on Jl. Samanhudi No. 27, Hamdan, Medan and the Putra Wiliam Booth Orphanage located on Jl. K. L. Yos Sudarso No. 10, Medan. This study uses primary data for hypothesis testing. While the data collection method used is a questionnaire that was distributed to the study sample. The sample used in this study were 101 respondents. Data analysis technique used in this research is to use Pearson Product Moment correlation analysis method which is done with the help of SPSS 25 for Windows software. The results of data analysis show that the correlation value of product moment is -0.868 . This means that there is a negative relationship between empathy and loneliness. The influence of empathy variable on loneliness is 75.3 percent, the remaining 24.7 percent is influenced by other factors not examined. From this study, we can also know that empathy held by children at Putri Evangeline Orphanage and Putra Wiliam Booth Orphanage are included in the high category. Loneliness felt by children is included in the low category. And empathy was proven to have a negative and significant relationship to loneliness in children raised at Putri Evangeline Orphanage and Putra Wiliam Booth Orphanage.
\end{abstract}

Keywords: empathy, loneliness, and orphanage.

\begin{abstract}
Abstrak
Penelitian ini bertujuan untuk mengetahui hubungan antara empathy (empati) dengan loneliness (kesepian) anak yang diasuh di Panti Asuhan Putri Evangeline Booth dan Panti Asuhan Putra Wiliam Booth. Penelitian ini dilakukan di Panti Asuhan Putri Evangeline Booth yang berlokasi di Jl. Samanhudi No. 27, Hamdan, Medan dan Panti Asuhan Putra Wiliam Booth yang berlokasi di Jl. K. L. Yos Sudarso No. 10, Medan. Penelitian ini menggunakan data primer untuk pengujian hipotesis. Sedangkan metode pengumpulan data yang digunakan adalah kuesioner yang dibagikan kepada sampel penelitian. Sampel yang digunakan dalam penelitian ini sebanyak 101 responden. Teknik analisis data yang dilakukan dalam penelitian ini adalah dengan menggunakan metode analisis korelasi Product Moment Pearson yang dilakukan dengan bantuan software SPSS 25 for Windows. Hasil analisis data menunjukkan nilai kolerasi product moment sebesar $-0,868$. Ini berarti terdapat hubungan negatif antara empathy dengan loneliness. Pengaruh variabel empathy terhadap loneliness adalah sebesar 75,3 persen sedangkan sisanya sebesar 24,7 persen dipengaruhi oleh faktor lain yang tidak diteliti. Dari penelitian ini juga diketahui bahwa empathy yang dimiliki anak di Panti Asuhan Putri Evangeline dan Panti Asuhan Putra Wiliam Booth termasuk dalam kategori yang tinggi. Loneliness yang dirasakan anak termasuk dalam kategori yang rendah. Dan empathy terbukti memiliki hubungan yang negatif dan signifikan terhadap loneliness pada anak yang diasuh di Panti Asuhan Putri Evangeline dan Panti Asuhan Putra Wiliam Booth.
\end{abstract}

Kata kunci: Empathy, loneliness, panti asuhan.

\section{Pendahuluan}

Anak adalah investasi dan harapan masa depan bangsa serta sebagai penerus generasi di masa mendatang. Anak merupakan individu yang berbeda dengan orang dewasa, baik secara fisik maupun psikologis. Sementara anak cenderung didominasi oleh pola berpikir yang bersifat egosentrik, berbeda dengan orang dewasa yang sudah mampu berpikir empati dan sosial, begitu juga dalam aspek daya berpikir, anak masih terbatas dengan hal yang konkret, sedangkan orang dewasa sudah mampu berpikir abstrak dan universal.

Anak yang bertempat tinggal yang tinggal di panti asuhan, adalah anak-anak yang hidup tanpa pengawasan dan bimbingan dari orang tua kandung mereka setiap harinya, biasanya anak-anak tersebut berstatus yatim piatu, yatim ataupun piatu dimana salah satu atau kedua orangtua mereka 
telah meninggal, namun ada juga anak-anak panti asuhan yang masih memiliki kedua orang tua, namun karena kesulitan ekonomi orang tua tersebut menitipkan anaknya di panti asuhan. Anak-anak panti asuhan melewatkan hari-harinya tanpa kehadiran kedua orang tuanya. Mereka jarang sekali atau bahkan tidak sama sekali bertemu kedua orang tuanya sehingga anak-anak panti asuhan tersebut tidak mendapatkan kasih sayang, perhatian dan dukungan secara langsung dari kedua orang tuanya.

Anak yang tinggal di panti asuhan umumnya adalah balita sampai dengan remaja yang berumur 18 tahun. Masa remaja merupakan masa transisi antara masa anak-anak menuju masa dewasa. Masa di mana individu akan meninggalkan masa anak-anaknya menuju tahap selanjutnya. Batubara (2010) menjelaskan bahwa remaja adalah masa peralihan yang dilalui individu saat beranjak dari masa kanak-kanak menuju masa dewasa. Pada periode perkembangannya, remaja dituntut untuk menguasai salah satu tugas perkembangan yaitu perkembangan sosial. Pada periode ini, individu tidak hanya dituntut untuk bersosialisasi dengan keluarga, namun juga dengan masyarakat sehingga individu dapat berbaur dan menyesuaikan diri dengan norma yang berlaku di masyarakat (Prayitno, 2006).

Tinggal di panti asuhan juga dapat berdampak negatif bagi anak karena kehidupan panti asuhan memungkinkan anak mengalami penurunan emosi yang mengakibatkan gangguan pada anak seperti sikap menarik diri, tidak mampu membentuk hubungan yang hangat dan dekat dengan orang lain, tidak mampu menyesuaikan diri, sehingga hubungan mereka bersifat terbatas dan tanpa perasaan. Penelitian Hartini (2000) menunjukkan gambaran bahwa kebutuhan psikologis anak yang memiliki kepribadian yang inferior, pasif, apatis, menarik diri, mudah putus asa, penuh dengan ketakutan dan kecemasan. Sehingga anak panti asuhan akan sulit menjalin hubungan sosial dengan orang lain. Disamping itu, mereka menunjukkan perilaku yang negatif, takut melakukan kontak dengan orang lain, lebih suka sendirian, menunjukkan rasa bermusuhan dan lebih egosentrisme.

Jika selama ini kita beranggapan bahwa anak yang tinggal di panti asuhan itu hanyalah anak yatim piatu, maka jawaban itu kurang tepat karena pada November 2018, terdapat sebuah temuan oleh Kementrian Sosial Republik Indonesia (Kemensos), bahwa sekitar 67\% anak yang tinggal di panti asuhan masih memiliki keluarga, baik keluarga inti maupun kerabat dekat. Pada keluarga inti sendiri biasanya sudah tidak utuh lagi. Bisa terjadi karena salah satu diantara orang tuanya sudah meninggal dunia atau bisa juga disebabkan karena perpisahan kedua orang tuanya akibat perceraian. Sedangkan kerabat dekat sendiri adalah yang masih memiliki hubungan dekat dengan anak atau kedua orang tuanya seperti kakek, nenek, paman, atau bibi (www.kompasiana.com).

Seperti anak panti asuhan Bina Insani yang berada di Provinsi Kepulauan Riau yang terdiri dari anak yatim piatu. Dan ada juga yang memiliki orang tua, namun orang tua mereka tidak mampu untuk membiayai hidup mereka. Sehingga orang tua mereka lebih memilih menitip anaknya di panti asuhan. Pada panti asuhan Bina Insani tersebut, terdapat dua orang kakak beradik yang berasal dari Dumai, Provinsi Riau. Mereka berdua sudah 2 (dua) tahun dititipkan orang tuanya di panti asuhan ini. N yang kini masih belajar di Madrasah Islamiyah (MI) Kijang mengaku sangat rindu kepada orang tuanya yang tinggal dan bekerja di Dumai. Sedangkan R, adik N yang masih berusia 4 tahun tentu saja masih sangat membutuhkan kehadiran orang tua di sisinya (www.kompasiana.com).

Tidak hanya $\mathrm{N}$ dan $\mathrm{R}$ yang mengalami nasib tersebut, beberapa dari temannya yang juga tinggal di panti asuhan tersebut juga senasib dengan $\mathrm{N}$ dan $\mathrm{R}$. Mereka dititipkan di panti asuhan karena kemiskinan yang menghimpit orang tua mereka. Seperti A yang berusia 12 tahun yang dititipkan orang tuanya karena tidak mampu untuk membiayai hidup anaknya. Selain itu terdapat pula satu anak di panti asuhan Bina Insani yang tuna wicara. Dia tidak bisa berbicara sedikit pun. L atau yang sering disapa dengan Leo juga dititipkan karena orang tuanya tidak sanggup membiayai sekolahnya (www.kompasiana.com).

Beberapa anak seperti yang disebutkan di atas adalah beberapa contoh anak panti asuhan yang tidak mendapatkan peran dari orang tuanya untuk menjaga dan merawatnya. Hanya para petugas panti asuhan sajalah yang menjadi teman bagi anak-anak tersebut. Hal inilah yang memicu adanya kesepian dalam diri masing-masing anak yang tinggal di panti asuhan.

Berdasarkan hasil wawancara yang dilakukan terhadap beberapa anak perempuan yang terdapat di Panti Asuhan Evangeline Booth yang berada di Jalan Samanhudi No. 27 Medan, dapat diketahui bahwa di panti asuhan tersebut terdapat beberapa anak yang salah satunya berinisial AR yang suka menghindari kontak mata, tidak ikut berbaur dengan teman-teman yang lain bahkan pada saat ditanya 
dia hanya menjawab dengan jawaban yang singkat saja. Hal ini tidak hanya terjadi pada AR saja, melainkan pada beberapa anak lainnya. Terlebih pada anak yang berusia lebih muda (SD dan SMP). Begitu pula pada anak laki-laki yang terdapat pada Panti Asuhan Wiliam Booth yang terdapat pada jalan K. L. Yos Sudarso No. 10 Medan. Anak laki-laki yang terdapat pada panti asuhan diketahui beberapa diantaranya merasa bahwa mereka seperti tidak memiliki teman yang dapat diajak berbicara. Seperti anak laki-laki yang berinisial HN yang sering merasa terasing dari temantemannya. Ia tidak banyak melakukan aktivitas bersama dengan teman-teman yang lainnnya, ia cenderung hanya bermain sendiri dan juga sering terlihat menghayal (melamun).

Berdasarkan kasus serta hasil wawancara di atas, dapat diperoleh gambaran tentang fenomena yang terjadi pada anak yang diasuh di panti asuhan. Pada kenyataannya, peran pengasuh tidak dapat menggantikan peran orang tua seutuhnya, dikarenakan para pengasuh harus berbagi perhatian dengan begitu banyak anak asuh lainnya yang menyebabkan kurangnya kasih sayang, kehangatan dan perhatian terhadap anak yang diharapkan dapat menggantikan peran dari orang tua. Tidak adanya figur kelekatan dalam hubungan yang intim seperti anak yang tidak ada orang tuanya atau kurangnya perhatian, dan pengalaman akan cinta kasih maka hal yang timbul adalah loneliness (Oguz \& Cakir, 2014).

Kesepian atau loneliness menurut Peplau dan Perlman (dalam Oguz \& Cakir, 2014) kesepian adalah perasaan emosi yang dirasakan ketika individu beranggapan bahwa kehidupan sosialnya lebih kecil daripada apa yang mereka inginkan, atau ketika individu merasa tidak puas dengan kehidupan sosialnya. Adapun Bruno (2000) mendefinisikan kesepian sebagai suatu keadaan mental dan emosional yang terutama dicirikan oleh adanya perasaan-perasaan terasing dan kurangnya hubungan yang bermakna dengan orang lain. Individu yang kesepian akan merasa dirinya tidak bahagia, tidak menarik, takut membuka diri, mudah depresi dan merasa terasing. Selanjutnya Sudarman (2010) menyatakan bahwa individu yang mengalami kesepian juga memiliki masalah dalam memandang dirinya sendiri, merasa tidak berguna, merasa gagal, merasa tidak ada yang peduli, merasa terpuruk dan berbagai perasaan negatif lainnya. Kesepian atau perasaan loneliness yang dialami oleh seseorang merupakan rasa sepi dalam dirinya sendiri atau jiwanya walaupun ia dalam lingkungan orang ramai.

Salah satu faktor yang mempengaruhi loneliness adalah empathy. Hal ini dibuktikan dari hasil penelitian dari Caro, dkk., (2017) yang menyatakan bahwa empathy memiliki hubungan yang signifikan terhadap loneliness yang dialami seseorang. Hubungan tersebut bersifat negatif yang berarti semakin tinggi empathy seseorang, maka semakin rendah tingkat loneliness-nya. Atau sebaliknya, semakin rendah empathy seseorang maka semakin tinggi pula tingkat loneliness yang dirasakannya.

Papalia, dkk., (2008) menyatakan bahwa empathy merupakan kemampuan untuk memposisikan diri pada posisi orang lain dan merasakan apa yang dirasakan oleh orang lain. Sejalan dengan pendapat ini, Hurlock (2000) menyatakan bahwa empathy adalah kemampuan seseorang untuk mengerti tentang perasaan dan emosi orang lain serta kemampuan untuk membayangkan diri sendiri di tempat orang lain.

Eisenberg (2002) menjelaskan terdapat dua jenis empathy. Pertama adalah empathy afektif, yakni kemampuan untuk berbagi emosi dengan orang lain. Empathy afekif adalah kecenderungan seseorang untuk mengalami perasaan emosional orang lain yaitu ikut merasakan ketika orang lain merasa sedih, menangis, terluka, menderita, bahkan disakiti. Mereka akan merasa takut atau merasakan derita orang lain saat melihat orang lain mengalaminya. Sebaliknya dengan jenis empathy yang kedua, yaitu empathy kognitif. Ini merupakan kemampuan untuk memahami emosi orang lain. Empathy kognitif difokuskan pada proses intelektual untuk memahami perspektif orang lain dengan tepat dan menerima pandangan mereka, misalnya membayangkan perasaan orang lain ketika marah, kecewa, senang, memahami keadaan orang lain dari; cara berbicara, dari raut wajah, cara pandang dalam berpendapat (Eisenberg, 2002).

Beadle, dkk., (2012) dalam penelitiannya juga menyatakan bahwa secara keseluruhan, dimensidimensi dari empathy memiliki hubungan yang signifikan dengan perasaan loneliness. Hasil tersebut juga didukung oleh Penelitian Brewie dan Klarke (2015) yang juga menyatakan bahwa empathy memiliki hubungan yang nyata terhadap loneliness. 
Tabel 1.

Perbandingan Mean Empirik dan Mean Hipotetik Loneliness

\begin{tabular}{lcccccccc}
\hline \multirow{2}{*}{ Variabel } & \multicolumn{4}{c}{ Mean Hipotetik } & \multicolumn{4}{c}{ Mean Empirik } \\
\cline { 2 - 8 } & Min & Max & Mean & SD & Min & Max & Mean & SD \\
\hline Loneliness & 35 & 175 & 105 & 23.33 & 57 & 94 & 68.93 & 7.07
\end{tabular}

Dari hasil penelitian terdahulu dapat diketahui faktor-faktor lainnya yang berhubungan dengan loneliness salah satunya adalah fungsi keluarga, persepsi penerimaan teman sebaya, dan kecerdasan sosial. Penelitian Hidayati (2018) menyatakan bahwa family fungctioning memiliki hubungan yang negatif dan signifikan terhadap loneliness pada remaja. Artinya, jika suatu keluarga memiliki family fungctioning yang tinggi maka anak (remaja) sebagai salah satu anggotanya akan memiliki loneliness yang rendah. Namun jika family fungctioning yang dimiliki rendah maka tingkat loneliness yang dialami akan meningkat.

Selain family fungctioning, persepsi penerimaan teman sebaya juga memiliki hubungan dengan loneliness yang dialami oleh para remaja. Penelitian terdahulu yang dilakukan oleh Triani (2012) berhasil membuktikan bahwa persepsi penerimaan teman sebaya memiliki pengaruh yang signifikan terhadap tingkat kesepian (loneliness) yang dialami oleh remaja. Faktor lainnya yang berhubungan dengan loneliness adalah kecerdasan sosial. Hasil penelitian yang dilakukan Garvin (2017) menemukan hasil yang menyatakan bahwa semakin tinggi tingkat kecerdasan sosial pada remaja, maka akan semakin rendah pula tingkat kesepian (loneliness) yang dialami oleh remaja, demikian pula dengan sebaliknya. Dengan semakin rendahnya tingkat kecemasan sosial remaja, maka tingkat kesepian (loneliness) yang dialami oleh remaja akan semakin tinggi.

\section{Metode Penelitian}

Subjek pada penelitian ini adalah anak-anak panti asuhan Evangeline Booth sebanyak 40 orang dan panti asuhan William Booth sebanyak 40 orang. Anak yang masih berada di tingkat pendidikan sekolah dasar (SD) termasuk ke dalam populasi penelitian. Total jumlah populasi penelitian adalah 80 orang. Dikarenakan jumlah populasi yang terbatas, maka pengambilan sampel dilakukan dengan metode sensus (total sampling) yang mengambil seluruh anggota populasi menjadi sampel penelitian.

Pengumpulan data dilakukan dengan menggunakan skala Likert dengan 5 alternatif jawaban yaitu SS (sangat setuju), S (setuju), N (Netral), TS (tidak setuju), dan STS (sangat tidak setuju). Terdiri dari pernyataan favourable dan unfavourable. Penelitian ini menggunakan 2 skala, yaitu skala Loneliness yang disusun berdasarkan aspek-aspek Loneliness yang dikemukakan oleh Bruno (2000) dan skala Empathy yang disusun berdasarkan aspek-aspek yang dikemukakan oleh Batson dan Coke.

Jumlah aitem dalam Skala Loneliness adalah 35 aitem. Skala ini memiliki nilai reliabilitas $\alpha$ yang cukup tinggi yaitu sebesar 0,902 dengan validitas yang bergerak dari 0,307 sampai 0,637. Sedangkan untuk skala Empathy memiliki jumlah aitem sebanyak 33 aiem. Nilai reliabilitas skala adalah 0,904 dan nilai validitasnya berkisar antara 0,319 sampai 0,659 .

Analisis data dilakukan dengan bantuan SPSS Statistics 23 for Windows.

\section{Hasil dan Pembahasan}

\section{Gambaran Umum Variabel Penelitian}

Pada skala loneliness jumlah aitem yang layak digunakan setelah uji instrument adalah sebanyak 35 aitem, dengan skor penilaian 1 sampai 5, sehingga skor minimum yang dapat diperoleh pada skala loneliness berjumlah 35 dan skor maksimalnya berjumlah 175. Mean hipotetik loneliness berjumah 105 dan standar deviasi sebesar 23,33. Sedangkan mean empirik loneliness berjumlah 68,93 dan standar deviasi sebesar 7,07. Sehingga perbandingan antara mean hipotetik dan mean empirik pada variabel loneliness (tabel 1) dapat disimpulkan mean hipotetik lebih besar dari mean empiric (105 > 68,93). Hal ini menunjukkan bahwa loneliness pada anak yang diasuh di Panti Asuhan Putri Evangeline dan Panti Asuhan Putra Wiliam Booth secara rata-rata termasuk rendah. 
Pada skala empathy jumlah aitem yang layak digunakan setelah uji instrument adalah sebanyak 33 aitem, dengan skor penilaian 1 sampai 5, sehingga skor minimum yang dapat diperoleh pada skala empathy berjumlah 33 dan skor maksimalnya berjumlah 165. Mean hipotetik empathy berjumlah 99 dan standar deviasi sebesar 22,00. Sedangkan mean empirik dihitung berdasarkan data hasil jawaban responden. Diketahui bahwa mean empirik empathy berjumlah 133,73 dan standar deviasinya 6,41. Sehingga perbandingan antara mean hipotetik dan mean empirik pada variabel empathy (tabel 2) dapat disimpulkan mean empirik lebih besar dari mean hipotetik $(99<133,73)$. Hal ini menunjukkan bahwa empathy pada anak yang diasuh di Panti Asuhan Putri Evangeline dan Panti Asuhan Putra Wiliam Booth secara rata-rata termasuk tinggi.

\subsection{Uji Asumsi}

Terdapat beberapa persyaratan yang harus dilakukan untuk melakukan pengujian hipotesis, yaitu uji asumsi normalitas dan juga linearitas untuk mengetahui korelasi diantara masing-masing variabel penelitian.

Uji normalitas dilakukan untuk mengetahui bahwa sampel yang berasal dari populasi yang terdistribusi normal. Hasil uji normalitas pada penelitian ini menggunakan One-sample Kolmogorov Smirnov. Data dinyatakan berdistribusi normal apabila mendapatkan hasil signifikansi $\mathrm{p}>0.05$ (Azwar, 2011). Hasil uji normalitas dapat dilihat pada tabel 3 berikut.

Tabel 2.

Perbandingan Mean Empirik dan Mean Hipotetik Empathy

\begin{tabular}{lcccccccc}
\hline \multirow{2}{*}{ Variabel } & \multicolumn{4}{c}{ Mean Hipotetik } & \multicolumn{4}{c}{ Mean Empirik } \\
\cline { 2 - 9 } & Min & Max & Mean & SD & Min & Max & Mean & SD \\
\hline Empathy & 33 & 165 & 99 & 22.00 & 108 & 144 & 133.73 & 6.41 \\
\hline
\end{tabular}

Berdasarkan hasil uji normalitas dari tabel diatas, maka dapat diketahui bahwa data yang digunkan dalam penelitian ini telah berdistribusi secara normal karena nilai signifikansi p yang dihasilkan adalah sebesar 0,200 yang lebih besar dari 0,05.

Uji linearitas dilakukan untuk mengetahui apakah distribusi data pada variabel empathy dan variabel loneliness memiliki hubungan yang linier. Uji linearitas dilakukan dengan menggunakan teknik Test for Linearity. Variabel memiliki hubungan yang linier apabila nilai signifikansi (linearity) p < 0,05, sedangkan jika nilai signifikansi (linearity) p > 0,05 maka variabel tidak memiliki hubungan yang linier (Azwar, 2011). Hasil uji linearitas dapat dilihat pada tabel 4 di bawah ini.

Tabel 3.

Hasil Uji Linearitas

\begin{tabular}{lcll}
\hline Variabel & F & Sig. & Keterangan \\
\hline $\begin{array}{l}\text { Loneliness } \\
\text { Empathy }\end{array}$ & 362.857 & 0.000 & $\begin{array}{l}\text { Linear } \\
(\mathrm{p}<0,05)\end{array}$ \\
\hline
\end{tabular}

Berdasarkan tabel uji linearitas diatas diketahui bahwa nilai signifikansi (linearity) mendapatkan hasil 0,000 , sehingga nilai $\mathrm{p}<0,05$. Dengan hasil tersebut maka dapat disimpulkan bahwa empathy memiliki hubungan linear dengan loneliness.

Dua uji asumsi yang telah dilakukan memiliki hasil yang baik, selanjutnya karena telah memenuhi persyaratan maka dapat dilakukan uji hipotesis. 


\subsection{Uji Hipotesis}

Metode analisis korelasi yang digunakan adalah Product Moment Pearson. Dari nilai yang diperoleh, diketahui empathy memiliki hubungan yang signifikan terhadap loneliness. Hasil uji hipotesis dapat dilihat pada tabel 5 di bawah. Berdasarkan tabel tersebut, dapat dilihat bahwa hasil nilai signifikansi yang dihasilkan oleh korelasi Pearson adalah sebesar $-0,868$ dengan signifikansi $0,000(\mathrm{p}<0,5)$. Sehingga dapat disimpulkan bahwa empathy memiliki hubungan yang signifikan dengan loneliness pada anak yang diasuh di Panti Asuhan Putri Evangeline dan Panti Asuhan Putra Wiliam Booth. Selain itu, berdasarkan Tabel 6 di bawah, dapat diketahui juga nilai sumbangan efektif $R$ square yang menginformasikan besarnya pengaruh variabel empathy terhadap loneliness. Nilai $R$ square yaitu 0,753. Ini berarti variabel empathy memiliki pengaruh sebesar 75,3 persen terhadap variabel loneliness sedangkan sisanya sebesar 24,7 persen dipengaruhi oleh faktor lain seperti penolakan, perasaan tidak dicintai, gelisah, tidak membuka diri, dan sebagainya.

Tabel 4.

Hasil Analisis Korelasi Product Moment Pearson

\begin{tabular}{llrr}
\multicolumn{3}{c}{ Correlations } & \\
& & Empathy & \multicolumn{1}{c}{ Loneliness } \\
\hline Empathy & Pearson Correlation & 1 & $-.868^{* *}$ \\
\cline { 2 - 4 } & Sig. (2-tailed) & 101 & .000 \\
\cline { 2 - 4 } & $\mathrm{N}$ & $-.868^{* * *}$ & 101 \\
\hline \multirow{2}{*}{ Loneliness } & Pearson Correlation & .000 & 1 \\
\cline { 2 - 4 } & Sig. (2-tailed) & 101 & 101 \\
\cline { 2 - 4 } & $\mathrm{N}$ & & \\
\hline **. Correlation is significant at the 0.01 level (2-tailed).
\end{tabular}

Tabel 7.

Tabel sumbangan efektif

\begin{tabular}{|c|c|c|c|c|c|}
\hline & & $\mathrm{R}$ & R Squared & Eta & Eta Squared \\
\hline $\begin{array}{l}\text { Loneliness } \\
\text { Empathy }\end{array}$ & * & -.868 & .753 & .919 & .844 \\
\hline
\end{tabular}

Berdasarkan hasil tersebut, maka dapat diketahui bahwa empathy memiliki hubungan yang arahnya negatif terhadap loneliness. Sehingga semakin tinggi rasa empathy yang dimiliki anak, maka akan semakin rendah tingkat loneliness yang dirasakan anak tersebut, begitu pula sebaliknya.

\subsection{Pembahasan}

Panti asuhan merupakan salah satu lembaga untuk membentuk perkembangan anak-anak yang tidak memiliki keluarga ataupun yang tidak tinggal bersama dengan keluarga. Anak-anak panti asuhan diasuh oleh pengasuh yang menggantikan peran orang tua dalam mengasuh, menjaga dan memberikan bimbingan kepada anak agar anak menjadi manusia dewasa yang berguna dan bertanggung jawab atas dirinya dan terhadap masyarakat di kemudian hari. Pada anak panti asuhan atau yatim piatu tidak ada kesempatan untuk menikmati kasih sayang ayah atau ibu (Ali \& Asrori, 2004). Gangguan tingkah laku yang terjadi pada anak yang selama berada di rumah titipan atau panti asuhan merupakan contoh akibat kurangnya kebutuhan akan kasih sayang orang tua. 
Kesepian atau loneliness menurut Peplau dan Perlman (dalam Oguz \& Cakir, 2014) adalah perasaan emosi yang dirasakan ketika individu beranggapan bahwa kehidupan sosialnya lebih kecil daripada apa yang mereka inginkan, atau ketika individu merasa tidak puas dengan kehidupan sosialnya. Kesepian atau perasaan loneliness yang dialami oleh seseorang merupakan rasa sepi dalam dirinya sendiri atau jiwanya walaupun ia dalam lingkungan orang ramai. Individu yang kesepian akan merasa dirinya tidak bahagia, tidak menarik, takut membuka diri, mudah depresi dan merasa terasing. Salah satu faktor yang berhubungan dengan loneliness adalah empathy.

Empathy merupakan kemampuan untuk memposisikan diri pada posisi orang lain dan merasakan apa yang dirasakan oleh orang lain. Empathy sebagai respon afektif dan kognitif yang kompleks pada distress emosional orang lain. Terdapat dua aspek empathy yaitu komponen afektif dan komponen kognitif. Komponen afektif adalah merasakan apa yang dirasakan oleh orang lain sedangkan komponen kognitif adalah memahami apa yang orang lain rasakan, adanya prespective taking (Baron \& Bryne, 2005). Sehingga jika seseorang memiliki empathy yang tinggi akan ia akan cenderung merasakan loneliness pada tingkat yang rendah.

Hasil yang diperoleh dalam penelitian ini sejalan dengan hasil penelitian yang dilakukan Sari dan Listiandini (2015) yang menyatakan bahwa ada hubungan yang negatif signifikan antara empathy dengan kesepian (loneliness). Hal ini dibuktikan dengan nilai signifikansi sebesar 0,000 yang lebih kecil dari 0,05 , serta hasi uji korelasi menunjukkan nilai $r=-0,324$. Hubungan tersebut bersifat negatif yang berarti semakin tinggi empathy seseorang, maka semakin rendah tingkat loneliness-nya. Atau sebaliknya, semakin rendah empathy seseorang maka semakin tinggi tingkat loneliness yang dirasakannya.

Hasil yang diperoleh dalam penelitian ini juga sejalan dengan hasil penelitian yang dilakukan oleh Marilaf Caro, dkk., (2017) yang juga menemukan bahwa empathy memiliki hubungan yang signifikan terhadap loneliness yang dialami seseorang. Beadle, dkk., (2012) dalam penelitiannya juga menyatakan bahwa secara keseluruhan, dimensi-dimensi dari empathy memiliki hubungan yang signifikan dengan perasaan loneliness. Serta hasil penelitian ini juga sejalan dengan hasil yang ditemukan Brewie dan Klarke (2015) yang juga menyatakan bahwa empathy memiliki hubungan yang nyata terhadap loneliness.

\section{Kesimpulan dan Saran}

\subsection{Kesimpulan}

Dari penelitian yang telah dilakukan, peneliti dapat mengambil kesimpulan bahwa empathy terbukti memiliki hubungan yang negatif signifikan dengan loneliness pada anak yang diasuh di Panti Asuhan Putri Evangeline dan Panti Asuhan Putra Wiliam Booth. Hubungan negatif ini memiliki arti semakin tinggi rasa empathy yang dimiliki anak, maka akan semakin rendah tingkat loneliness yang dirasakan anak tersebut, begitu pula sebaliknya. Nilai koefisien korelasi Product Moment (r) sebesar -0,868, dengan signifikansi $(\mathrm{p})$ sebesar $0,000(\mathrm{p}<0,05)$. Sumbangan efektif variabel empathy terhadap loneliness sebesar 75,3 persen, selebihnya 24,7 persen dipengaruhi oleh faktor lain yang tidak diteliti.

\subsection{Saran}

Berdasarkan hasil yang diperoleh, diketahui bahwa tingkat empathy yang tinggi akan berdampak positif terhadap kehidupan sosial anak sehingga disarankan kepada orang tua maupun orang tua asuh untuk melatih empathy anak sedini mungkin. Orang tua maupun orang tua asuh mengajarkan anak melatih aspek-aspek yang terdapat dalam empathy yaitu kehangatan, kelembutan, sikap peduli, dan belas kasih sehingga empathy anak dapat terus tumbuh. Untuk pemerintah maupun masyarakat, agar lebih banyak memperhatikan kesejahteraan anak. Ketika anak tumbuh dalam keadaan tidak bahagia, hal itu akan mempengaruhi masa depan dan kepercayaan diri anak. Akan sangat disayangkan potensi anak tersebut yang akan terbuang sia-sia karena setiap anak adalah masa depan negara.

\section{Daftar Rujukan}

[1] Ali, M. \& Asrori, M. 2004. Psikologi Remaja (Perkembangan Peserta Didik). Jakarta: Bumi Aksara.

[2] Azwar, S. 2011. Reliabilitas dan Validitas. Yogyakarta: Pustaka Belajar.

[3] Baron, R. A. \& Byrne, D. 2005. Psikologi Sosial (10th Edition). Jakarta: Erlangga. 
[4] Batubara, J. R. L. 2010. Adolescent Development (Perkembangan Remaja). Jurnal Sari Pediatri. 12 (1), 21 29. Diakses pada tanggal 22 Juli 2018 dari https://saripediatri.org/index.php/saripediatri/article/view/540/476

[5] Beadle J. N., Brown V., Keady B., \& Tranel, D. 2012. Trait Empathy as a Predictor of Individual Differences in Perceived Loneliness. Journal of Psychological Reports. Vol. 110 (1), 3-15. Diakses pada tanggal 14 Agustus 2018 dari https://doi.org/ 10.2466/07.09.20.PR0.110.1.3-15

[6] Brewie, G. \& J. Klarke. (2015). Cyberbullying, Self-Esteem, Empathy and Loneliness. Computers in Human Behavior. 48, 255-260. Diakses pada tanggal 10 Agustus 2018 dari https://www.sciencedirect.com/ science/article/pii/S0747563215001016

[7] Bruno, F. J. 2000. Conquer Loneliness: Menaklukkan Kesepian. Jakarta: PT. Gramedia Pustaka Utama.

[8] Caro, M., San-Martín, M., Delgado-Bolton, R., \& Vivanco, L. 2017. Empathy, Loneliness, Burnout, and Life Satisfaction in Chilean Nurses of Palliative Care and Homecare Services. Elsevier Espana. 27, (6). 379-386. Diakses pada tanggal 21 Juli 2018 dari https://www.researchgate.net/publication/318925812_Empathy_loneliness_burnout_and_life_satisfact i_on_in_Chilean_nurses_of_palliative_care_and_homecare_services

[9] Eisenberg, N. 2002. Prosocial Development in Early Adulthood: A Longitudinal Study. Journal of Personality and Social Psychology. 82, (6). 993-1003. Diakses pada tanggal 20 Juli 2018 dari https://digitalcommons.unl.edu/cgi/viewcontent.cgi?article=1297\&context=psychfacpub

[10]Garvin. 2017. Hubungan Kecerdasan Sosial Dengan Kesepian Pada Remaja. Jurnal Muara Ilmu Sosial, Humaniora, dan Seni. 1, (2). 93-99. Diakses pada tanggal 21 Juli 2018 dari https://www.researchgate.net/publication/323258725_Hubungan_Kecerdasan_Sosial_dengan_Kesepian_p ada_Remaja

[11] Hartini, N. 2000. Deskripsi Kebutuhan Psikologi Pada Anak Panti Asuhan. Jurnal Dinamika Sosial. 1 (1). 109-118. Diakses pada tanggal 22 Juli 2018 dari http://journal.unair.ac.id/JPDS@karakteristikkebutuhan-psikologis-anak-panti-asuhan-article-1896-media-26-category-8.html

[12] Hidayati, D., S. (2018). Family Functioning dan Loneliness pada Remaja dengan Orang Tua Tunggal. Jurnal Ilmiah Psikologi Terapan. 6, (1), 54-62. Diakses pada tanggal 20 Juli 2018 dari http://ejournal.umm.ac.id/ index.php/jipt/article/download/5432/pdf

[13] Hurlock, B., E. (2000). Perkembangan Anak. Jilid 2. Jakarta: Erlangga.

[14] Oguz, E. \& Cakir, O. 2014. Relationship Between The Levels of Loneliness and Internet Addiction. Anthropologist Journal. 18, (1). Diakses pada tanggal 14 Agustus 2018 dari https://www.academia.edu/35231306/Relationship_between_the_Levels_of_Loneliness_and_Internet _Addiction

[15] Papalia, D. E., Old, S. \& W., Feldman. 2008. Human Development. Jakarta: Prenada Media Group.

[16] Prayitno, E. 2006. Psikologi Perkembangan Remaja. Padang: Angkasa Raya.

[17] Sari, P. R., \& Listiandini, R. A. 2015. Hubungan Antara Resiliensi Dengan Kesepian (Loneliness) Pada Dewasa Muda Lajang. Jurnal PESAT. 6, 45-51. Diakses pada tanggal 2 Agustus 2018 dari https://ejournal. gunadarma.ac.id/index.php/pesat/article/view/1337/1191

[18] Sudarman. 2010. Kesepian pada Remaja yang Tinggal di Panti Asuhan (Studi Kasus). [Online]. Diakses

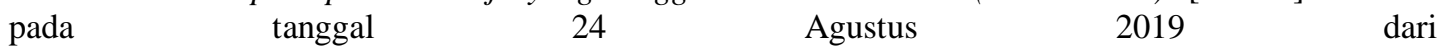
http://publication.gunadarma.ac.id/bitstream/123456789/1056/1/10504176.pdf

[19] Triani, A. 2012. Pengaruh Persepsi Penerimaan Teman Sebaya Terhadap Kesepian Pada Remaja. Jurnal Penelitian dan Pengukuran Psikologi. Unversitas Negeri Jakarta. 1, (1). Diakses pada tanggal 20 Juli 2018 dari http://journal.unj.ac.id/unj/index.php/jppp/article/view/343/291

[20] www.kompasiana.com. 2013. Anak Panti Asuhan yang Rindu Orang tua. Diakses pada tanggal 23 Agustus 2019

dari https://www.kompasiana.com/blogeraan.blogspot.com/552c5b0b6ea834f1738b456c/anak-pantiasuhan-yang-rindu-orangtua

[21] www.kompasiana.com. 2018. Pilihan Dilematis Anak Panti Asuhan. Diakses pada tanggal 23 Agustus 2019 dari https://www.kompasiana.com/sucyatia/5d196e91097f3637fc459ca2/pilihan-dilematisanak-panti-asuhan?page $=$ all 